Article

\title{
Macronutrient Intake in Adults Diagnosed with Meta- bolic Syndrome: using the Health Examinee (HEXA) Cohort
}

\author{
Hyerim Park ${ }^{1,2}$, Anthony Kityo ${ }^{1}$, Yeonjin Kim ${ }^{1,2}$, Sang-Ah Lee ${ }^{1,2^{*}}$
}

\author{
${ }^{1}$ Department of Preventive Medicine, Kangwon National University School of Medicine, \\ Gangwon, South Korea \\ ${ }^{2}$ Interdisciplinary Graduate Program in Medical Bigdata Convergence, Kangwon National \\ University School of Medicine, Gangwon, South Korea \\ * Correspondence: SAL, sangahlee@kangwon.ac.kr, +82-33-250-8871
}

\begin{abstract}
Macronutrient intake is important in the prevention and management of Metabolic Syndrome (MetS). We characterized energy and macronutrient intake of Koreans diagnosed with MetS at recruitment of the Health Examinee (HEXA) cohort. We included 130,423 participants aged 40-69 years for analysis. Odds ratios (OR) and $95 \%$ confidence intervals (CI) were estimated to evaluate the intake of macronutrient. Low energy ( $\mathrm{OR}=0.94,95 \% \mathrm{CI}$ : $0.89-0.98)$ and fat intake (OR=0.91, 95\% CI: 0.86-0.97) was observed among 50-59 year-old men. Only postmenopausal women had lower intake of total energy ( $\mathrm{OR}=0.95,95 \%$ CI: $0.92-$ 0.97 ) while low fat intake was observed in all women ( $\mathrm{OR}=0.8095 \% \mathrm{CI}: 0.77-0.83)$. For carbohydrate intake, the OR were 1.14 (95\% CI: 1.08-1.22) and 1.17 (95\% CI: $1.08-1.27$ ) among women in their 50 's and 60 's respectively. Protein intake was low (OR=0.90, 95\% CI: $0.86-0.95)$ and (OR=0.88, 95\% CI: 0.82-0.94) among women in their 50's and 60's respectively. High intake of plant carbohydrates in women $(\mathrm{OR}=1.16,95 \%$ CI: 1.12-1.20) and plant protein in both genders (OR=1.09, 95\% CI: 1.05-1.13) were observed, but low intake of total energy, fat and animal-source carbohydrates in both genders. Fat intake was low regardless of food source. In conclusion, high consumption of plant-source and low consumption of animalsource macronutrients was observed in Korean adult diagnosed MetS.
\end{abstract}

Keywords: Macronutrient intake; Metabolic syndrome; the Korean Health Examinee (HEXA) stud

\section{Introduction}

Interconnected risk factors of metabolic syndrome (MetS) such as abdominal obesity, atherogenic dyslipidemia, raised blood pressure and insulin resistance increase the risk of coronary heart disease, other cardiovascular diseases (CVD) and type 2 diabetes mellitus (T2DM)[1-3]. CVD and T2DM are global health issues with a high prevalence and increasing burden of economics in public health [4,5]. MetS has a high prevalence in many countries $[6,7]$ and it has as well gradually increased in Korea over the last 10 years $[8,9]$. Although the etiology of MetS is unclear, various factors such as genetics, metabolism and the environment including diet may contribute to its development [10]. A recent review highlighted 
a possible interconnection between gut microbial dysfunction, Non-alcoholic fatty liver disease (NAFLD) and colonic diverticulosis as possible underlying risk factors of MetS [11].

Diet is an important factor in the prevention and management of MetS [12]. Previous studies reported conflicting results on the association between macronutrient intake and risk of MetS according to gender, geographical location and food sources [13-15]. In 55-80 years old men and women with MetS, intake of total fat above the Acceptable Macronutrient Distribution range (AMDR) and lower intake of energy and carbohydrates were reported [13]. Plant protein, especially soy protein and wheat gluten compared to animal proteins were linked to reduced risk of MetS components [14]. In a meta-analysis of observational studies, high carbohydrate intake was associated with increased odds of developing MetS [15]. The observational study using national survey data from the United States and Korea showed not only different percentages of energy intake from carbohydrate, protein and fat between the two countries, but also increased risk of MetS with high carbohydrate intake only in Korean men and women[16]. This finding was attributed to a high percentage of energy from carbohydrates in Korean compared to the US.

Differential association between protein intake were also observed in Korean adults, a positive association between animal protein and MetS components (abdominal obesity, low HDL-C and hyperglycemia) and a protective effect of plant protein on blood pressure in men, while null findings were observed in women [17]. The percentage of energy from carbohydrates in men and particularly refined grains, including white rice in women were associated with MetS [18].

The patterns of macronutrient intake in the Korean population with MetS have been rarely reported. Therefore, this study aimed to identify the characteristics of total energy, carbohydrate, protein, and fat intake in participants diagnosed with MetS at recruitment of the Health Examinees (HEXA) cohort, considering the plant and animal sources of each macronutrient. We also examined whether macronutrient intake differs by diagnosis of each metabolic syndrome component.

\section{Materials and Methods}

\subsection{Study population}

The Health Examinees (HEXA) Study is a community-based, large genomic cohort that was conducted in Korea from 2004 to 2013. Detailed information about the study design have been described in previous studies $[19,20]$. For the homogeneity and comparability of participants, previous HEXA study was updated to Health Examinees-Gem (HEXAG) [21]. A total of 139,345 participants aged $40-69$ years remained in the HEXA-G data after excluding withdrawers $(n=11)$ and participants from invalid institutions $(n=31,375)$. In addition, 8922 participants were excluded among the HEXA-G. These included participants with missing baseline information on hypertension, diabetes mellitus or hyperlipidemia history $(n=600)$; missing data on blood pressure, fasting glucose, triglycerides, high density lipoprotein (HDL)-cholesterol, and waist circumference (WC) $(n=4540)$; and those with energy intake $<800$ or $\geq 4000 \mathrm{kcal} /$ day in men and $<500$ or $\geq 3500 \mathrm{kcal} /$ day in women $(n=3782)$. Finally, 130,423 participants of whom 43,850 were men and 86,573 were 
women remained in the final sample (Figure 1). All participants gave informed written consent prior to participating in the study. The Institutional Review Board of the Seoul National University Hospital approved this study for statistical analysis (IRB No. E-1503-103-657).

\subsection{Dietary Assesment}

Dietary information was collected using a validated semi-quantitative food frequency questionnaire (FFQ) developed for the Korean Genome and Epidemiology study (KoGES) [22]. Trained interviewers assessed the intake 106 food items consumed by participants over the past year. Food consumption frequencies were classified into nine levels (from "never" to "three times or more a day"), and portion size into three levels (one-half, one, one and a half servings). Energy, carbohydrate, protein, and fat intake were calculated using a food composition table developed by the Korean Health and Industry of Development Institute [23]. Plant and animal-based carbohydrate, protein, and fat intake were determined after classification according to food source. Classification of macronutrients according to plant or animal sources was based on the guidelines of KoGES database (https://www.kdca.go.kr/contents.es?mid=a40504100200). Based on the guideline, the weighted amount of constituent foods based on the representative recipe of each food item constituting the mixed dishes are given. These amounts were used to evaluate mixed dishes and calculate plant or animal source macronutrients. The percentage of energy from each macronutrient was calculated using the standard conversion factors: carbohydrate $4 \mathrm{kcal} / \mathrm{g}$, protein $4 \mathrm{kcal} / \mathrm{g}$, fat $9 \mathrm{kcal} / \mathrm{g}$.

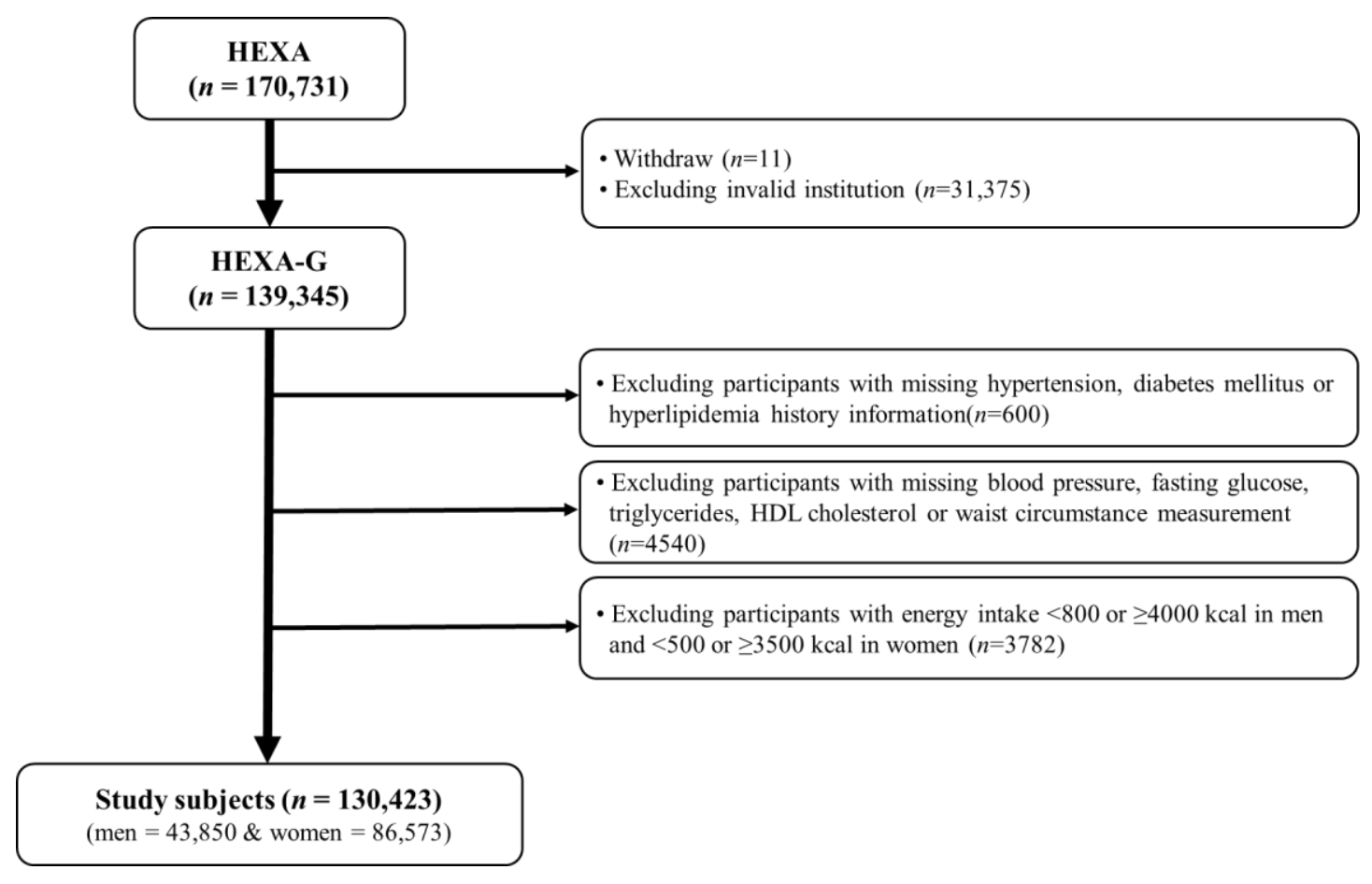

Figure 1. Flow diagram of analytical sample in this study using the Health Examinees (HEXA) cohort.

\subsection{Definition of Metabolic syndrome}

MetS was defined using the National Cholesterol Education Program Adult Treatment Panel III (NCEP-ATP III) [24], modified for the 
Asian guideline for WC [25]. Participants who met three or more of the following criteria were classified as having MetS: (1) WC $\geq 90$ for men and $\geq 80 \mathrm{~cm}$ for women; (2) triglycerides (TG) $\geq 150 \mathrm{mg} / \mathrm{dL}$ or drug treatment for elevated triglycerides; (3) HDL-cholesterol $\leq 40$ for men and $\leq 50 \mathrm{mg} / \mathrm{dL}$ for women; (4) systolic blood pressure (SBP) $\geq 130 \mathrm{mmHg}$, diastolic blood pressure (DBP) $\geq 85 \mathrm{mmHg}$ or drug treatment for elevated blood pressure; and (5) fasting blood glucose $\geq 100 \mathrm{mg} / \mathrm{dL}$ or drug treatment for elevated fasting blood glucose.

\subsection{Covariates}

Demographic and lifestyle factors such as age, marital status, education, family income, occupation, body mass index (BMI), health-related behaviors, and macronutrient intake were included. Age was categorized into three groups: 40-49, 50-59, and 60-69 years old. Marital status, education, family income, and occupation were categorized into two groups each. Marital status: yes (married, cohabit), no (single, separated, divorced, widowed, others). Education: 12 years, 12 years or more. Family income: below $\$ 3000, \$ 3000$ and above per month. Occupation: occupied (11 types of occupation including senior officials and managers and professionals etc), unoccupied (unoccupied, housewife, and others). BMI was calculated as weight in kilograms divided by the square of height in meters $(\mathrm{kg} / \mathrm{m} 2)$. Non-smokers were defined as those who had smoked less than 400 cigarettes during their lifetime. Former smokers were defined as those who had smoked more than 400 cigarettes during their lifetime but did not smoke at the baseline. Participants who had smoked more than 400 cigarettes during their lifetime and still smoked at the baseline classified as current smokers. Non-current drinkers were defined as those who had never consumed any alcoholic drink during their lifetime or those who did not consume alcohol at baseline. Current drinkers were defined as those who still consumed alcohol. Regular exercise was classified into two groups (yes: regular exercise that caused body sweating; and no: otherwise). Menopausal status was classified as either pre-menopausal women who currently experience monthly menstrual cycle or post-menopausal women who have gone a year without menstrual flow.

\subsection{Statistical Analysis}

The Mantel-Haenszel chi-square test for categorical variables and general linear model (GLM) for continuous variables were used to analyze the demographic and lifestyle factors of participants according to quartiles of total energy intake. Categorical variables such as marital status, education, family income, occupation, smoking, drinking and regular exercise were presented as percentage (\%). Continuous variables including age, BMI, energy and macronutrient (carbohydrate, protein, fat) intake were presented as median and interquartile range (IQR). Multivariable logistic regression models were used to examine the characteristics of energy and macronutrient intake in participants with MetS diagnosis at recruitment after adjusting for age, BMI, education, family income, occupation, smoking, drinking, regular exercise, and energy intake. Results are presented as odds ratio (OR) and $95 \%$ confidence interval (CI). Pvalue $<0.05$ (2-tailed test) was considered statistically significant. All data were analysed using SAS (version 9.4; SAS Institute Inc., Cary, NC, USA). 


\section{Results}

Demographic and lifestyle factors of participants according to metS are presented in Table 1. Both men and women diagnosed with MetS were significantly older (men: OR=1.03, 95\% CI: 1.03-1.04; women: OR=1.07, 95\% CI: 1.06-1.07) and had higher BMI (men: OR=1.51, 95\% CI: 1.49-1.53; women: OR=1.40, 95\% CI: 1.39-1.42) compared to controls. In addition, both men and women with MetS were more likely to be current smokers (men: OR=1.37, 95\% CI: 1.30-1.45; women: OR=1.34, 95\% CI:1.181.53), had occupation (men: $\mathrm{OR}=1.20,95 \% \mathrm{CI}$ : 1.12-1.28; women: $\mathrm{OR}=1.12$ , 95\% CI: 1.08-1.17), were less educated (men: OR=0.89 , 95\% CI: 0.85-0.94; women: $0.75,95 \%$ CI: $0.71-0.79$ ) and less likely to exercise regularly (men : OR=0.85, 95\% CI: 0.81-0.89; women: OR=0.90, 95\% CI: 0.86-0.94) compared to controls. Current drinking was more frequent among men with MetS (OR=1.09, 95\% CI: 1.03-1.16). Women with MetS were less likely to be current drinkers ( $\mathrm{OR}=0.80,95 \% \mathrm{CI}$ : $0.76-0.84)$, and were less likely to earn $\geq 30,000$ USD a month (OR=0.87, 95\% CI: 0.83-0.91) compared to controls (table 1). Socio-demographic and lifestyle factors of participants according to quartiles of total energy intake are presented in supplementary table 1 .

Table 2 shows energy and macronutrient intake of participants according to MetS and MetS components. Total energy intake was lower in men and women with MetS (men: $\mathrm{OR}=0.95$; women: $(\mathrm{OR}=0.97)$. Low fat intake was observed in men ( $\mathrm{OR}=0.93$ ), but high carbohydrate intake, low protein and fat intake was observed in women (carbohydrate; $\mathrm{OR}=1.14$, protein; $\mathrm{OR}=0.90$, fat; $\mathrm{OR}=0.80$ ). When MetS components were characterized according to macronutrient intake by gender, men and women with abdominal obesity consumed more total energy (men: $\mathrm{OR}=1.08$; women: $\mathrm{OR}=1.04)$. Conversely, low energy intake was observed in participants with low HDL-cholesterol (men: $\mathrm{OR}=0.94$; women: $\mathrm{OR}=0.97$ ), high blood pressure (men: $\mathrm{OR}=0.94$; women: $\mathrm{OR}=0.97$ ) and hyperglycemia (men: $\mathrm{OR}=0.95$; women: $\mathrm{OR}=0.96$ ). High carbohydrate intake was reported in men and women with high triglycerides (OR=1.05 and 1.11 in men and women respectively) and low HDL-cholesterol (OR=1.14 and 1.17 in men and women, respectively), but only in women with high blood pressure $(\mathrm{OR}=1.08)$. In contrast, low carbohydrate intake was observed among those with hyperglycemia (men: $\mathrm{OR}=0.91$; women: $\mathrm{OR}=0$.) and in men with high blood pressure $(\mathrm{OR}=0.93)$. Participants with hyperglycemia reported high intake of proteins $(\mathrm{OR}=1.07$ in men and 1.04 in women). Regarding fat, low intake was linked to high triglycerides (men: $\mathrm{OR}=0.94$; women: $\mathrm{OR}=0.84$ ), low HDL-cholesterol (men: $\mathrm{OR}=0.81$; women: $\mathrm{OR}=0.79$ ) and high blood pressure (men: $\mathrm{OR}=0.94$; women: $\mathrm{OR}=$ $0.93)$.

The intake of macronutrients according to baseline MetS diagnosis stratified by gender and age group are presented in table 3. Low energy $(\mathrm{OR}=0.94)$ and fat intake $(\mathrm{OR}=0.91)$ was only predominant among 50-59year-old men. Among women in their 50's and 60's, a high carbohydrate intake (OR=1.14 and 1.17 respectively), and a low protein intake ( $\mathrm{OR}=0.90$ and 0.88 respectively) were observed. Moreover, low fat intake was observed in women in their 40,50 and $60^{\prime}$ s $(\mathrm{OR}=0.87,0.81$, and 0.78 respectively). The median intake of energy and macronutrient intake for each MetS component stratified by age group is presented in supplementary 
table 1 while the corresponding odds ratios are presented in supplementary figure 1.

The characteristics of each macronutrient intake from plant and animal food sources are presented in Figure 2. Women diagnosed with MetS consumed more carbohydrate from plant $(\mathrm{OR}=1.16)$, but less from animal sources $(\mathrm{OR}=0.91)$. Low intake of animal carbohydrate was also observed in men $(\mathrm{OR}=0.92)$. In both gender, low intake of animal proteins was observed (OR=0.97 and 0.91 for men and women, respectively) while high intake of plant protein was reported (men: $\mathrm{OR}=1.05$, women: $\mathrm{OR}=1.09$. All participants diagnosed with MetS had low intake of plant fat (men: OR:0.97; women: $\mathrm{OR}=0.89$ ) and animal fat (men: $\mathrm{OR}=0.95$; women: OR:0.87). Characteristics of macronutrient intake according to MetS components also varied according to the source of macronutrients. Men with high triglycerides had a high intake of plant carbohydrates and proteins $(\mathrm{OR}=1.08$ and 1.09 respectively), but low intake of animal carbohydrates, protein and fat $(\mathrm{OR}=0.92,0.96$, and 0.94 in order $)$. Similarly, men with low HDL-cholesterol reported high intake of plant carbohydrates $(\mathrm{OR}=1.15)$ and low intake of animal protein and fat ( $\mathrm{OR}=0.89$ and 0.85 respectively). Men with high blood pressure had a high intake of plant protein $(\mathrm{OR}=1.05)$ and a low intake of animal carbohydrate and fat $(\mathrm{OR}=0.93$ and 0.96 respectively). High intake of plant protein $(\mathrm{OR}=1.05)$ and animal fat $(\mathrm{OR}=1.05)$, but low intake of plant fat $(\mathrm{OR}=0.94)$ was observed in men with hyperglycemia. On the other hand, women with high triglycerides had a high intake of plant carbohydrates and protein $(\mathrm{OR}=1.13$ and 1.06 respectively), but low intake of animal carbohydrates $(\mathrm{OR}=0.95)$. Moreover, women with low HDL-cholesterol had high intake of plant carbohydrates and proteins $(\mathrm{OR}=1.21$ and 1.06 respectively), but low intake of animal protein $(\mathrm{OR}=0.91)$. High blood pressure among women was characterized by high intake of plant carbohydrate and protein $(\mathrm{OR}=1.08$ and 1.10 respectively) but low intake of animal protein and fat $(\mathrm{OR}=0.96$ and 0.93 , respectively). Women who had hyperglycemia reported low intake of animal carbohydrate (OR=0.95). 


\section{nutrients}

\section{Discussion}

This study was designed to evaluate macronutrient intake of participants diagnosed with MetS at recruitment of the HEXA cohort. Total energy and fat intake were low in both men and women diagnosed with MetS. Carbohydrate intake was high, but protein intake was low only in women. A high intake of total energy and fat were observed among 50-59-year old men with MetS. A high carbohydrate and low protein intake was shown in women aged 50 and above. However, low intake of fat was reported regardless of age group. Participants diagnosed with MetS had low intake of carbohydrate and protein from animal foods, but high intake of carbohydrate and protein from plant foods. On the other hand, fat intake was low in both men and women regardless of source. Moreover, macronutrient intake varied across diagnosis of MetS components and this variation also depended on the source of macronutrient.

Consistent with our findings, MetS participants consumed lower total energy compared to non-MetS participants [26,27]. In a 2005-2007 survey, Koreans 40 years and above with Mets consumed less energy than those without MetS [28]. In contrast, high energy intake was observed among MetS participants $[29,30]$ while no differences in energy intake were observed between MetS and non-MetS participants [31]. In our study, total energy intake might have been restricted by participants prior to MetS diagnosis, because of changes in food intake even when atleast one of the five MetS components are diagnosed.

Reports have indicated excessive intake of carbohydrates at the expense of other macronutrients in elderly Koreans [32] and a positive association between high carbohydrate intake and risk of MetS in women [32-37]. A typical Korean diet is rich in refined grains especially white rice and noodles. Studies from Asian countries have reported a positive association between frequent consumption of refined grains and MetS [38,39]. Excessive intake of carbohydrates in form of refined grains increases the glycemic load and leads to postprandial hyperglycemia, hyperinsulinemia and insulin resistance, which plays a key role in MetS, dyslipidemia, obesity, and T2DM [40]. Women with MetS reported high carbohydrate intake unlike men. The gender difference is consistent with higher intake carbohydrates in Korean women than men. Thus, carbohydrate substitution or improving the quality of carbohydrates will likely benefit Korean women. Similar to our findings regarding plant carbohydrates, women but not men with MetS consumed more energy from refined grains and white rice [41]. These results suggest that gender is an important factor in the choice of carbohydrate sources among Koreans suffering from MetS; women consuming more carbohydrates from plant sources. A Korean-style diet mainly characterized by grains and vegetables, may be associated with elevated risk of MetS [42]. In contrast, low intake of animal carbohydrate among subjects with MetS might reflect overall low consumption of milk in the Korean diet [43] since animal carbohydrate mainly come from milk and dairy products. Several studies have reported low intake of milk and other dairy products among MetS cases [44-47].

Women with MetS consumed less absolute protein than those without MetS and absolute protein intake decreased with age suggesting that Koreans restrict protein intake as they age. Korean young and middle aged adults consume $71.0 \mathrm{~g} / \mathrm{d}$ of proteins, way above the RDA of $50 \mathrm{~g} / \mathrm{d}$ [48] while inadequate protein intake is only evident among the elderly [49]. The association of protein intake with MetS are inconclusive, with some studies reporting positive [50-53] while others reporting negative findings among women [54]. A Korean study reported increased odds of abdominal obesity, hypertriglyceridemia and high fasting glucose especially in middle-aged women with low protein intake [55]. Since our study was a cross-sectional study, it is possible that Korean women under-reported their protein intake or restricted protein intake after diagnosis of one of the metS such as 
high blood pressure, low HDL-cholesterol and high triglycerides as reported in the current study. Absolute amount of protein intake from plant source in this population might be correlated with intake of refined carbohydrate, predominantly from white rice [49]. This might explain high intake of plant proteins among women diagnosed with MetS and some of its components in our study. Evidently, plant sources supplied more proteins than animal sources in this population. Korean studies have reported more intake of proteins from plants, predominantly grains with only $1 / 3$ of proteins from animal [56]. Elderly people tend to eat more plant proteins since they are easy to chew, have less appetite for animal foods and might restrict animal protein due to metabolic concerns [57]. Results on protein intake according to dietary sources, and MetS are inconsistent. Both cross-sectional and longitudinal studies have reported a positive association between animal protein and MetS risk factors [52], and a negative or null association between plant proteins and MetS components [53,58].

Fat consumption has gradually increased in Korea but still within the Acceptable Macronutrient Distribution range (AMDR) and lower than that of the US [59,60]. Lower consumption of animal source foods such as processed red meat in middle-aged Koreans has been reported [61]. Moreover, total unprocessed meat, particularly poultry consumption was inversely related with CVD risk among middle aged Koreans [61]. A semi-Western diet characterized by relatively high intakes of animal foods, was associated with a low risk of low HDL cholesterol [62]. Energy from total fat was associated with lower prevalence of MetS in both men and women. Similarly, participants with MetS were more likely to consume low percent of energy from fats [42]. Among individuals in the unbalanced Korean dietary pattern, individuals in the extreme consumption of this pattern had a lower percent of energy from fat and increased odds of MetS [36]. Percent of energy from fat was significantly lower in MetS participants compared to normal participants [63]. In contrast, dietary total fat positively influenced metabolic syndrome in Tehranian adults but the mean percent of calories from fat was 30\% [64] which is higher than our study. Longitudinal studies did not find any association between total fat and MetS but found inverse associations with vegetable fats but not animal fats [65]. Inconsistencies in findings might be due to different amounts of fats consumed in other countries vs Korea or the study designs employed. Some longitudinal studies and systematic reviews have reported no association between MUFAs, PUFAs and SFAs with Mets or CVD risk factors [65-67] suggesting that dietary sources of fatty acids rather than individual fatty acids and total fat intake should be considered in the interpretation of our findings. Culturally, meat dishes are usually consumed with vegetables, and it is notable that meat intake in Korea differs from Western style [68] which could underlie differences in the characteristics of fat intake among MetS subjects in Western countries and Korea.

Results of our study should be cautiously interpreted because of several limitations. First, because we used a cross-sectional study design, we could not examine any causal link between macronutrient intake and the risk of MetS. To be diagnosed with MetS, at least 3 or more of high blood pressure, diabetes mellitus, hypertriglyceride, low HDLcholesterol, and abdominal obesity must be present. Therefore, it is possible that participants changed their lifestyle prior to MetS diagnosis at recruitment. Second, we used a food frequency questionnaire to assess dietary intake. Since the food frequency method relies on participant memory, dietary intake could have been over or underestimated by participants. Third, current food and nutrient intake might differ from the intake assessed at recruitment of this study. Therefore, our findings might not reflect current intake and changes in dietary intake over time. Lastly, we could not evaluate the amount of alcohol consumed by participants because alcohol intake was not quantified in the HEXA study. However, several strengths could be noted. First, our results can be generalized to the entire Korean population aged 40-69 years since we analyzed a large sample of participants. Second, we used a FFQ that was previously validated for this population[22] . Hence it is possible that we reduced the measurement error in dietary measurement. 
Third, we stratified our analysis by dietary source of macronutrients to capture differential characteristics of macronutrients and MetS according to macronutrient source. Fourth, we adjusted for known confounders of dietary intake and MetS. Nevertheless, residual confounding cannot be completely excluded. Finally, we excluded participants who were undergoing treatment for any of MetS components, since these participants could have altered their nutrient intake after diagnosis.

\section{Conclusion}

We found low intake of total energy and fat in both men and women diagnosed with MetS, and high intake of carbohydrate and low intake of protein was only observed in women. Although people diagnosed with MetS have high carbohydrate, and low protein and fat intake, this characteristic varied according to the source of macronutrients. The intake of plant carbohydrates and protein was high, while the intake of animal carbohydrate and protein was low. On the other hand, fat consumption was low regardless of its source. Moreover, the intake of plant and animal-based macronutrients differed according to metabolic syndrome components. Longitudinal cohort studies with long follow-up duration and repeated dietary intake assessment are necessary to confirm these findings.

Author Contributions: The authors' responsibilities were as follows: S.-A.L. - designed and conducted the research, and had primary responsibility for the final content of the manuscript; H.P. and Y.K. - analyzed the data and performed the statistical analyses; H.P. and A.K. - wrote the manuscript. All authors read and approved the final manuscript.

\section{Funding: None}

Data Availability Statement: All data and materials used in this study will be available upon reasonable request from the corresponding author.

\section{Conflicts of Interest: None}

\section{References} disease and hypertension in low- and middle-income countries: A systematic review. BMC Public Health. 2018;18(1).

6. Raposo L, Severo M, Barros H, Santos AC. The prevalence of the metabolic syndrome in Portugal: The PORMETS study. BMC Public Health. 2017;17(1):1-9.

7. $\quad$ Aguilar M, Bhuket T, Torres S, Liu B, Wong RJ. Prevalence of the metabolic syndrome in the United States, 2003-2012. JAMA. 2015;313(19):1973-4.

8. Eun Lee S, Han K, Mi Kang Y, Kim S-O, Kyung Cho Y, Soo Ko K, Park J-Y, Lee K-U, Hee Koh E. Trends in the prevalence of metabolic syndrome and its components in South Korea: Findings from the Korean National Health Insurance Service Database (2009-2013) on Behalf of the Taskforce Team of Diabetes Fact Sheet of the Korean Diabetes Association. 2018;

9. Lim S, Shin H, Song JH, Kwak SH, Kang SM, Yoon JW, Choi SH, Cho S Il, Park KS, Lee HK, Jang HC, Koh KK. Increasing prevalence of metabolic syndrome in Korea: The Korean National Health and Nutrition Examination Survey for 1998-2007. Diabetes Care. 2011;34(6):1323-8. 
10. Elder SJ, Lichtenstein AH, Pittas AG, Roberts SB, Fuss PJ, Greenberg AS, McCrory MA, Bouchard TJ, Saltzman E, Neale

MC. Genetic and environmental influences on factors associated with cardiovascular disease and the metabolic syndrome. J Lipid Res. 2009;50(9):1917-26.

11. Milovanovic T, Pantic I, Dragasevic S, Lugonja S, Dumic I, Rajilic-Stojanovic M. The Interrelationship Among NonAlcoholic Fatty Liver Disease, Colonic Diverticulosis and Metabolic Syndrome. J Gastrointest Liver Dis. 2021;

12. de la Iglesia R, Loria-Kohen V, Zulet MA, Martinez JA, Reglero G, de Molina AR. Dietary strategies implicated in the prevention and treatment of metabolic syndrome [Internet]. Vol. 17, International Journal of Molecular Sciences. MDPI AG; 2016.

13. Julibert A, Bibiloni M del M, Tur JA. Dietary fat intake and metabolic syndrome in adults: A systematic review. Nutr Metab Cardiovasc Dis. 2019;29(9):887-905.

14. Chalvon-Demersay T, Azzout-Marniche D, Arfsten J, Egli L, Gaudichon C, Karagounis LG, Tomé D. A systematic review of the effects of plant compared with animal protein sources on features of metabolic syndrome1-3. J Nutr. 2017;147(3):281-92.

15. Liu YS, Wu QJ, Xia Y, Zhang JY, Jiang YT, Chang Q, Zhao YH. Carbohydrate intake and risk of metabolic syndrome: A dose-response meta-analysis of observational studies. Nutr Metab Cardiovasc Dis. 2019;29(12):1288-98.

16. Ha K, Kim K, Chun OK, Joung H, Song Y. Differential association of dietary carbohydrate intake with metabolic syndrome in the US and Korean adults: Data from the 2007-2012 NHANES and KNHANES. Eur J Clin Nutr. 2018;72(6):848-60.

17. Chung S, Chung MY, Choi HK, Park JH, Hwang JT, Joung H. Animal protein intake is positively associated with metabolic syndrome risk factors in middle-aged korean men. Nutrients. 2020;12(11):1-15.

18. Song SJ, Lee JE, Song WO, Paik HY, Song YJ. Carbohydrate intake and refined-grain consumption are associated with metabolic syndrome in the korean adult population. J Acad Nutr Diet. 2014;114(1):54-62.

19. Kang D, Kim DH, Kim DH, Lee DH, Lee DH, Lee HJ, Moon JD, Leem JH, Lee JK, Lee JT, Lee KH, Yoo KY, Park MS, Han NG, Lee SA, Roh S, Lee SG, Kim SJ, et al. The health examinees (HEXA) study: Rationale, study design and baseline characteristics. Asian Pacific J Cancer Prev. 2015;16(4):1591-7.

20. Kim Y, Han B-G. Cohort Profile: The Korean Genome and Epidemiology Study (KoGES) Consortium. Int J Epidemiol. 2017;46(2):e20-e20.

21. Shin S, Lee H-W, Kim C, Lim J, Lee J, Lee S-A, Kang D. Egg Consumption and Risk of Metabolic Syndrome in Korean Adults: Results from the Health Examinees Study. Nutrients. 2017;9(7):687.

22. Ahn Y, Kwon E, Shim JE, Park MK, Joo Y, Kimm K, Park C, Kim DH. Validation and reproducibility of food frequency questionnaire for Korean genome epidemiologic study. Eur J Clin Nutr. 2007;61(12):1435-41.

23. National Rural Nutrition Institute. Food Composition Tables. 2016.

24. National Cholesterol Education Program (NCEP) Expert Panel on Detection, Evaluation and T of HBC in A. Third Report of the National Cholesterol Education Program (NCEP) Expert Panel on Detection, Evaluation, and Treatment of High Blood Cholesterol in Adults (Adult Treatment Panel III) final report. Circulation. 2002;106(25):3143-421.

25. Alberti KGMM, Zimmet P, Shaw J. Metabolic syndrome - A new world-wide definition. A consensus statement from the International Diabetes Federation. Diabet Med. 2006;23(5):469-80.

26. Delavar MA, Lye M-S, Lin Khor G, Tajuddin S, Syed B, Phd H, Hanachi P. Dietary patterns and the metabolic syndrome in middle aged women, Babol, Iran. Asia Pac J Clin Nutr. 2009;18(2):285-92.

27. Cabello-Saavedra E, Bes-Rastrollo M, Alfredo Martinez J, Diez-Espino J, Buil-Cosiales P, Serrano-Martinez M, Angel Martinez-Gonzalez M. Macronutrient Intake and Metabolic Syndrome in Subjects at High Cardiovascular Risk. Ann Nutr Met. 2010;56:152-9.

28. Moon H-K§, kong J-E. Assessment of Nutrient Intake for Middle Aged with and without Metabolic Syndrome Using 2005 and 2007 Korean National Health and Nutrition Survey *. J Nutr). 2010;43(1):69-78. 
29. Vasbinder A, Tinker LF, Neuhouser ML, Pettinger M, Hale L, Di C, Zaslavsky O, Hayman LL, Lin X, Eaton C, Wang D, Scherman A, Stefanick ML, Barrington WE, Reding KW. Risk of metabolic syndrome and metabolic phenotypes in relation to biomarker-calibrated estimates of energy and protein intakes: an investigation from the Women's Health Initiative. Am J Clin Nutr. 2021;113(3):706-15.

30. Nabuco HCG, Tomeleri CM, Sugihara Junior P, dos Reis Fernandes R, Cavalcante EF, Antunes M, Burini RC, Venturini D, Barbosa DS, Silva AM, Cyrino ES. Lower protein and higher carbohydrate intake are related with altering metabolic syndrome components in elderly women: A cross-sectional study. Exp Gerontol. 2018;103:132-7.

31. Skilton MR, Laville M, Cust AE, Moulin P, Bonnet F. The association between dietary macronutrient intake and the prevalence of the metabolic syndrome. Br J Nutr. 2021;100:400-7.

32. Jung WS, Park HY, Kim SW, Lim K. Sex-specific energy intakes and physical activity levels according to the presence of metabolic syndrome in korean elderly people: Korean national health and nutrition examination survey 2016-2018. Int J Environ Res Public Health. 2020;17(15):1-12.

33. Park HS, Kim SM, Lee JS, Lee J, Han JH, Yoon DK, Baik SH, Choi DS, Choi KM. Prevalence and trends of metabolic syndrome in Korea: Korean National Health and Nutrition Survey 1998-2001. Diabetes, Obes Metab. 2007;9(1):50-8.

34. Jeppesen J, Schaaf P, Jones C, Zhou MY, Chen YD, Reaven GM. Effects of low-fat, high-carbohydrate diets on risk factors for ischemic heart disease in postmenopausal women. Am J Clin Nutr. 1997;65(4):1027-33.

35. Lee YJ, Song SJ, Song YJ. High-carbohydrate diets and food patterns and their associations with metabolic disease in the Korean population. Yonsei Med J. 2018;59(7):834-42.

36. Oh HY, Kim MK, Lee M, Kim YO. Macronutrient Composition and Sodium Intake of Diet Are Associated with Risk of Metabolic Syndrome and Hypertension in Korean Women. Scuteri A, editor. PLoS One. 2013;8(10):e78088.

37. Kim K, Yun SH, Choi BY, Kim MK. Cross-sectional relationship between dietary carbohydrate, glycaemic index, glycaemic load and risk of the metabolic syndrome in a Korean population. Br J Nutr. 2008;100(3):576-84.

38. Kang Y, Lee K, Lee J, Kim J. Grain Subtype and the Combination of Grains Consumed Are Associated with the Risk of Metabolic Syndrome: Analysis of a Community-Based Prospective Cohort. J Nutr. 2020;150(1):118-27.

39. Murakami K, Sasaki S, Takahashi Y, Okubo H, Hosoi Y, Horiguchi H, Oguma E, Kayama F. Dietary glycemic index and load in relation to metabolic risk factors in Japanese female farmers with traditional dietary habits. Am J Clin Nutr. 2006;83(5):1161-9.

40. Augustin LSA, Kendall CWC, Jenkins DJA, Willett WC, Astrup A, Barclay AW, Björck I, Brand-Miller JC, Brighenti F, Buyken AE, Ceriello A, La Vecchia C, Livesey G, Liu S, Riccardi G, Rizkalla SW, Sievenpiper JL, Trichopoulou A, et al. Glycemic index, glycemic load and glycemic response: An International Scientific Consensus Summit from the International Carbohydrate Quality Consortium (ICQC). Nutr Metab Cardiovasc Dis. 2015;25(9):795-815.

41. Song SJ, Lee JE, Song WO, Paik HY, Song YJ. Carbohydrate intake and refined-grain consumption are associated with metabolic syndrome in the korean adult population. J Acad Nutr Diet. 2014;114(1):54-62.

42. Park S, Ahn J, Lee BK. Very-low-fat diets may be associated with increased risk of metabolic syndrome in the adult population. Clin Nutr. 2016;35(5):1159-67.

43. Jun S, Ha K, Chung S, Joung H. Meat and milk intake in the rice-based Korean diet: impact on cancer and metabolic syndrome. 2016;

44. Kim J. Dairy food consumption is inversely associated with the risk of the metabolic syndrome in Korean adults. J Hum Nutr Diet. 2013;26(SUPPL.1):171-9.

45. Kwon HT, Lee CM, Park JH, Ko JA, Seong EJ, Park MS, Cho BL. Milk intake and its association with metabolic syndrome in Korean: Analysis of the third Korea national health and nutrition examination survey (KNHANES III). J Korean Med Sci. 2010;25(10):1473-9. 
46. Shin H, Yoon YS, Lee Y, Kim C Il, Oh SW. Dairy product intake is inversely associated with metabolic syndrome in Korean adults: Anseong and ansan cohort of the Korean genome and epidemiology study. J Korean Med Sci. 2013;28(10):1482-8.

47. Otsuka R, Imai T, Kato Y, Ando F, Shimokata H. Relationship between number of metabolic syndrome components and dietary factors in middle-aged and elderly Japanese subjects. Hypertens Res. 2010;33(6):548-54.

48. KOSIS. Korean Statistical Information Service [Internet].

http://kosis.kr/statHtml/statHtml.do?orgId=101\&tblId=DT_1ET0291\&vw_cd=MT_ZTITLE\&list_id=F1H\&seqNo=\&lang_mo de=ko\&language=kor\&obj_var_id=\&itm_id=\&conn_path=MT_ZTITLE (Accessed 2019. 11. 13). 2019 [Accessed 2021 May 7]. Available from:

https://kosis.kr/eng/statisticsList/statisticsListIndex.do?menuId=M_01_01\&vwcd=MT_ETITLE\&parmTabId=M_01_01\&statI d=1973001\&themaId=\#SelectStatsBoxDiv

49. Park HA. Adequacy of protein intake among Korean Elderly: An analysis of the 2013-2014 Korea National Health and Nutrition Examination Survey Data. Korean J Fam Med. 2018;39(2):130-4.

50. Kyung Paik J, Park M, Shin JE, Jang SY, Shin JY. Dietary protein to carbohydrate ratio and incidence of metabolic syndrome in Korean adults based on a long-term prospective community-based cohort. Nutrients. 2020;12(11):1-13.

51. Tinker LF, Sarto GE, Howard B V, Huang Y, Neuhouser ML, Mossavar-Rahmani Y, Beasley JM, Margolis KL, Eaton CB,

Phillips LS, Prentice RL. Biomarker-calibrated dietary energy and protein intake associations with diabetes risk among postmenopausal women from the Women's Health Initiative. Am J Clin Nutr. 2011;94(6):1600-6.

Van Nielen M, Feskens EJM, Mensink M, Sluijs I, Molina E, Amiano P, Ardanaz E, Balkau B, Beulens JWJ, Boeing H, Clavel-Chapelon F, Fagherazzi G, Franks PW, Halkjaer J, Huerta JM, Katzke V, Key TJ, Khaw KT, et al. Dietary protein intake and incidence of type 2 diabetes in Europe: The EPIC-InterAct case-cohort study. Diabetes Care. 2014;37(7):1854-62.

53. Vasbinder A, Tinker LF, Neuhouser ML, Pettinger M, Hale L, Di C, Zaslavsky O, Hayman LL, Lin X, Eaton C, Wang D, Scherman A, Stefanick ML, Barrington WE, Reding KW. Risk of metabolic syndrome and metabolic phenotypes in relation to biomarker-calibrated estimates of energy and protein intakes: an investigation from the Women's Health Initiative. Am J Clin Nutr. 2021;113(3):706-15.

54. Appel LJ, Sacks FM, Carey VJ, Obarzanek E, Swain JF, Miller ER, Conlin PR, Erlinger TP, Rosner BA, Laranjo NM, Charleston J, McCarron P, Bishop LM. Effects of protein, monounsaturated fat, and carbohydrate intake on blood pressure and serum lipids: Results of the OmniHeart randomized trial. J Am Med Assoc. 2005;294(19):2455-64.

55. Oh C, No J. Does Protein Intake Affect Metabolic Risk Factors among Older Adults in Korea? J Obes Metab Syndr. 2017;26(4):266-73.

56. Chung S, Chung MY, Choi HK, Park JH, Hwang JT, Joung H. Animal protein intake is positively associated with metabolic syndrome risk factors in middle-aged korean men. Nutrients. 2020;12(11):1-15.

57. Berrazaga I, Micard V, Gueugneau M, Walrand S. The Role of the Anabolic Properties of Plant- versus Animal-Based Protein Sources in Supporting Muscle Mass Maintenance: A Critical Review. Nutrients. 2019;11(8):1825.

58. Shang X, Scott D, Hodge A, English DR, Giles GG, Ebeling PR, Sanders KM. Dietary protein from different food sources, incident metabolic syndrome and changes in its components: An 11-year longitudinal study in healthy communitydwelling adults. Clin Nutr. 2017;36(6):1540-8.

59. Ervin RB, Wright JD, Wang C-Y, Kennedy-Stephenson J. Dietary Intake of Fats and Fatty Acids for the United States Population: 1999-2000 [Internet]. 2004 [Accessed 2021 Apr 15]. Available from: www.cdc.gov/nchs/data/nhanes/

60. Baek Y, Hwang J-Y, Kim K, Moon H-K, Kweon S, Yang J, Oh K, Eun Shim J. Dietary intake of fats and fatty acids in the Korean population: Korea National Health and Nutrition Examination Survey, 2013. Nutr Res Pract. 2015;9(6):650-7.

61. Son J, Lee Y, Park K. Effects of processed red meat consumption on the risk of type 2 diabetes and cardiovascular diseases among Korean adults: the Korean Genome and Epidemiology Study. Eur J Nutr. 2019;58(6):2477-84. 
62. Oh HY, Kim MK, Lee M, Kim YO. Macronutrient Composition and Sodium Intake of Diet Are Associated with Risk of 290 Metabolic Syndrome and Hypertension in Korean Women. Scuteri A, editor. PLoS One. 2013;8(10):e78088.

63. Lee KW, Cho Y, Jo G, Park YK, Shin MJ. Association of dietary intakes of total and subtypes of fat substituted for carbohydrate with metabolic syndrome in Koreans. Endocr J. 2016;63(11):991-9.

64. Hekmatdoost A, Mirmiran P, Hosseini-Esfahani F, Azizi F. Dietary fatty acid composition and metabolic syndrome in Tehranian adults. Nutrition. 2011;27(10):1002-7.

65. Um YJ, Oh SW, Lee CM, Kwon HT, Joh HK, Kim YJ, Kim HJ, Ahn SH. Dietary fat intake and the risk of metabolic syndrome in Korean adults. Korean J Fam Med. 2015;36(5):245-52.

66. Chowdhury R, Warnakula S, Kunutsor S, Crowe F, Ward HA, Johnson L, Franco OH, Butterworth AS, Forouhi NG, Thompson SG, Khaw KT, Mozaffarian D, Danesh J, Di Angelantonio E. Association of dietary, circulating, and supplement fatty acids with coronary risk: A systematic review and meta-analysis. Ann Intern Med. 2014;160(6):398-406.

67. McCaulley M. Association of dietary, circulating, and supplement fatty acids with coronary risk. [Internet]. Vol. 161, Annals of internal medicine. American College of Physicians; 2014. p. 456.

68. Lee M-J, Popkin BM, Kim S. The unique aspects of the nutrition transition in South Korea: the retention of healthful elements in their traditional diet. Public Health Nutr. 2002;5(1a):197-203. 


\section{nutrients}

\section{MDPI}

Table 1. Socio-demographic and lifestyle factors according to MetS status, the HEXA-G study, 2004-2013

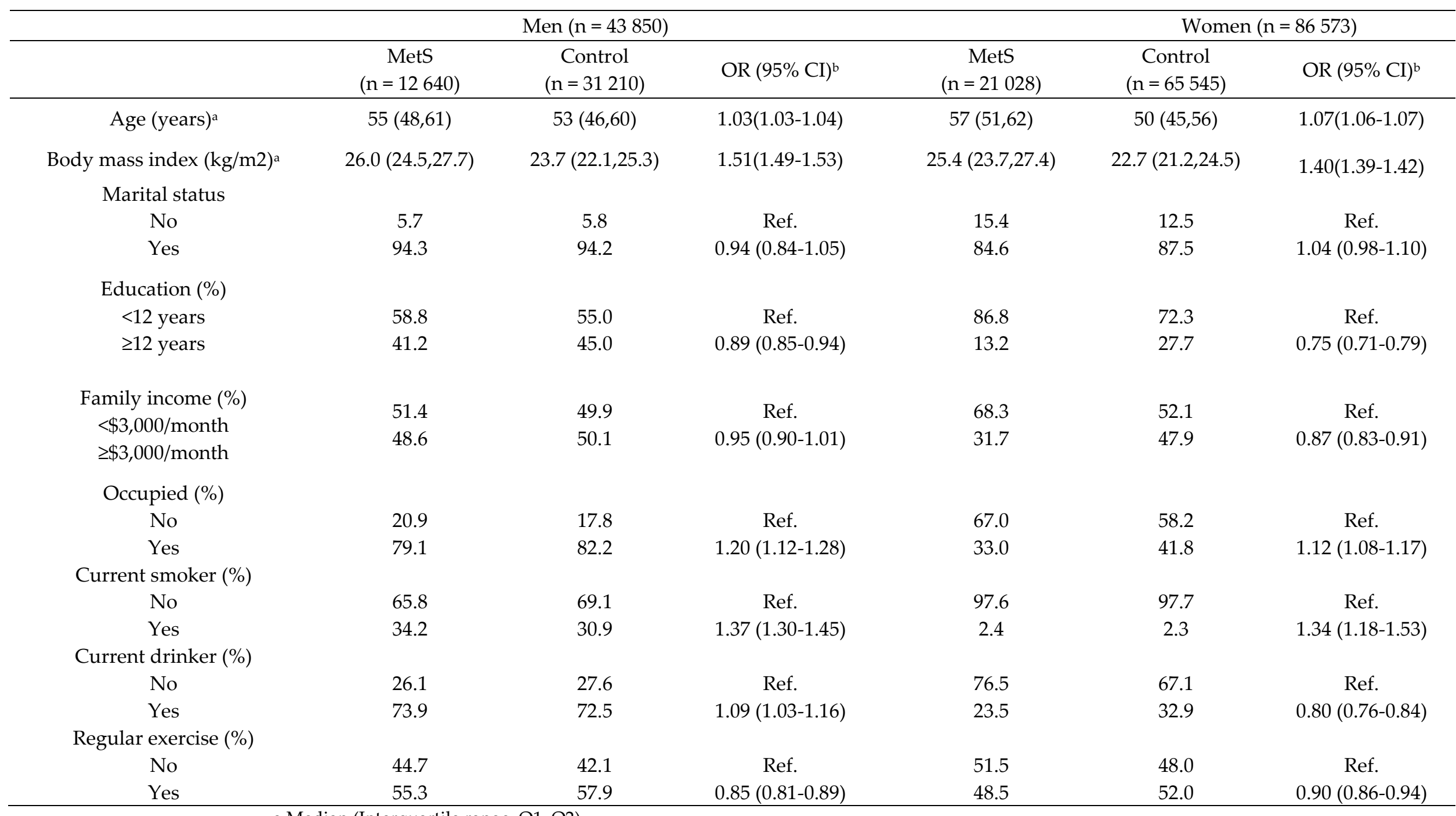


Table 2. Odds ratio (OR) and 95\% confidence intervals (CI) of metabolic syndrome (MetS) and its components according to macronutrient intake, the HEXA-G study, 2004-2013

\begin{tabular}{|c|c|c|c|c|c|c|c|c|}
\hline & \multicolumn{2}{|c|}{ Energy (Kcal/day) } & \multicolumn{2}{|c|}{ Carbohydrate(g/day) } & \multicolumn{2}{|c|}{ Protein (g/day) } & \multicolumn{2}{|c|}{ Fat (g/day) } \\
\hline & $\begin{array}{c}\text { Case/ } \\
\text { Controla }^{\text {Cont }} \\
\end{array}$ & $\begin{array}{c}\text { OR } \\
(95 \% \mathrm{CI})^{\mathrm{b}} \\
\end{array}$ & $\begin{array}{c}\text { Case/ } \\
\text { Controla }^{\text {Control }} \\
\end{array}$ & $\begin{array}{c}\text { OR } \\
(95 \% \mathrm{CI})^{\mathrm{b}} \\
\end{array}$ & $\begin{array}{c}\text { Case/ } \\
\text { Control }^{a} \\
\end{array}$ & $\begin{array}{c}\text { OR } \\
(95 \% \mathrm{CI})^{\mathrm{b}} \\
\end{array}$ & $\begin{array}{c}\text { Case/ } \\
\text { Controla }^{\text {Contro }} \\
\end{array}$ & $\begin{array}{c}\text { OR } \\
(95 \% \mathrm{CI})^{\mathrm{b}}\end{array}$ \\
\hline \multicolumn{9}{|l|}{ Men } \\
\hline MetS & $\begin{array}{l}1789(1525,2125) / \\
1781(1516,2117)\end{array}$ & $\begin{array}{c}0.95 \\
(0.92-0.98)\end{array}$ & $\begin{array}{l}318(277,370) / \\
317(276,368)\end{array}$ & $\begin{array}{c}0.97 \\
(0.93-1.03)\end{array}$ & $\begin{array}{c}59.5(47,75) / \\
58.4(47,74)\end{array}$ & $\begin{array}{c}0.98 \\
(0.94-1.02)\end{array}$ & $\begin{array}{l}27.4(19,38) / \\
27.3(19,38)\end{array}$ & $\begin{array}{c}0.93 \\
(0.90-0.96)\end{array}$ \\
\hline Abdominal obesity & $\begin{array}{l}1821(1546,2171) / \\
1769(1508,2100)\end{array}$ & $\begin{array}{c}1.08 \\
(1.05-1.12)\end{array}$ & $\begin{array}{l}321(279,377) / \\
316(275,366)\end{array}$ & $\begin{array}{c}0.97 \\
(0.91-1.03)\end{array}$ & $\begin{array}{c}60.7(48,77) / \\
57.8(46,73)\end{array}$ & $\begin{array}{c}1.04 \\
(0.99-1.10)\end{array}$ & $\begin{array}{l}28.4(20,40) / \\
26.9(19,37)\end{array}$ & $\begin{array}{c}1.03 \\
(0.99-1.07)\end{array}$ \\
\hline High triglycerides & $\begin{array}{l}1791(1526,2129) / \\
1778(1514,2113)\end{array}$ & $\begin{array}{c}0.97 \\
(0.95-1.00)\end{array}$ & $\begin{array}{l}318(277,371) / \\
317(276,368)\end{array}$ & $\begin{array}{c}1.05 \\
(1.00-1.10)\end{array}$ & $\begin{array}{c}59.3(47,74) / \\
58.3(47,74)\end{array}$ & $\begin{array}{c}0.98 \\
(0.94-1.01)\end{array}$ & $\begin{array}{l}27.7(19,38) / \\
27.1(19,38)\end{array}$ & $\begin{array}{c}0.94 \\
(0.91-0.97)\end{array}$ \\
\hline Low HDL-c & $\begin{array}{l}1778(1512,2109) / \\
1785(1520,2122)\end{array}$ & $\begin{array}{c}0.94 \\
(0.92-0.97)\end{array}$ & $\begin{array}{l}319(278,370) / \\
317(276,369)\end{array}$ & $\begin{array}{c}1.14 \\
(1.08-1.20)\end{array}$ & $\begin{array}{c}57.9(46,73) / \\
59.0(47,74)\end{array}$ & $\begin{array}{c}0.87 \\
(0.83-0.90)\end{array}$ & $\begin{array}{l}26.3(18,37) / \\
27.6(19,39)\end{array}$ & $\begin{array}{c}0.81 \\
(0.78-0.84)\end{array}$ \\
\hline High blood pressure & $\begin{array}{l}1776(1514,2109) / \\
1791(1526,2132)\end{array}$ & $\begin{array}{c}0.94 \\
(0.92-0.97)\end{array}$ & $\begin{array}{l}316(276,366) / \\
319(277,372)\end{array}$ & $\begin{array}{c}0.93 \\
(0.89-0.97)\end{array}$ & $\begin{array}{c}58.6(47,74) / \\
58.8(47,74)\end{array}$ & $\begin{array}{c}0.98 \\
(0.95-1.02)\end{array}$ & $\begin{array}{l}26.9(19,38) / \\
27.8(20,39)\end{array}$ & $\begin{array}{c}0.94 \\
(0.92-0.97)\end{array}$ \\
\hline Hyperglycemia & $\begin{array}{l}1768(1508,2100) / \\
1791(1524,2129)\end{array}$ & $\begin{array}{c}0.95 \\
(0.93-0.98) \\
\end{array}$ & $\begin{array}{c}315(275,365) / \\
319(277,371) \\
\end{array}$ & $\begin{array}{c}0.91 \\
(0.87-0.95) \\
\end{array}$ & $\begin{array}{c}58.8(47,74) / \\
58.7(47,74)\end{array}$ & $\begin{array}{c}1.07 \\
(1.04-1.11) \\
\end{array}$ & $\begin{array}{c}26.9(19,38) / \\
27.5(19,38)\end{array}$ & $\begin{array}{c}1.02 \\
(0.99-1.05)\end{array}$ \\
\hline \multicolumn{9}{|l|}{ Women $^{c}$} \\
\hline MetS & $\begin{array}{l}1617(1351,1924) / \\
1652(1359,1976)\end{array}$ & $\begin{array}{c}0.97 \\
(0.95-0.99)\end{array}$ & $\begin{array}{c}300(251,347) / \\
300(244,351)\end{array}$ & $\begin{array}{c}1.14 \\
(1.08-1.19)\end{array}$ & $\begin{array}{l}51.8(41,66) / \\
54.0(42,69)\end{array}$ & $\begin{array}{c}0.90 \\
(0.87-0.94)\end{array}$ & $\begin{array}{l}20.9(14,30) / \\
24.0(17,34)\end{array}$ & $\begin{array}{c}0.80 \\
(0.77-0.83)\end{array}$ \\
\hline Abdominal obesity & $\begin{array}{l}1643(1367,1957) / \\
1643(1349,1967)\end{array}$ & $\begin{array}{c}1.04 \\
(1.02-1.06)\end{array}$ & $\begin{array}{l}302(251,350) / \\
299(242,350)\end{array}$ & $\begin{array}{c}1.02 \\
(0.98-1.07)\end{array}$ & $\begin{array}{l}53.2(42,68) / \\
53.6(42,68)\end{array}$ & $\begin{array}{c}1.01 \\
(0.98-1.05)\end{array}$ & $\begin{array}{l}22.3(15,32) / \\
23.8(16,34)\end{array}$ & $\begin{array}{c}0.96 \\
(0.93-0.99)\end{array}$ \\
\hline High triglycerides & $\begin{array}{c}1624(1346,1940) / \\
1648(1360,1971)\end{array}$ & $\begin{array}{c}0.99 \\
(0.97-1.01) \\
\end{array}$ & $\begin{array}{c}300(248,349) / \\
300(245,350)\end{array}$ & $\begin{array}{c}1.11 \\
(1.07-1.16) \\
\end{array}$ & $\begin{array}{c}52.0(41,66) / \\
53.9(42,68)\end{array}$ & $\begin{array}{c}0.90 \\
(0.87-0.93) \\
\end{array}$ & $\begin{array}{l}21.3(14,31) / \\
23.8(16,34)\end{array}$ & $\begin{array}{c}0.84 \\
(0.82-0.87)\end{array}$ \\
\hline
\end{tabular}




\begin{tabular}{|c|c|c|c|c|c|c|c|c|}
\hline Low HDL-c & $\begin{array}{c}1629(1356,1943) / \\
1652(1358,1976)\end{array}$ & $\begin{array}{c}0.97 \\
(0.95-0.99)\end{array}$ & $\begin{array}{l}300(249,349) / \\
300(244,351)\end{array}$ & $\begin{array}{c}1.17 \\
(1.13-1.21)\end{array}$ & $\begin{array}{l}52.4(41,67) / \\
54.1(42,69)\end{array}$ & $\begin{array}{c}0.91 \\
(0.88-0.93)\end{array}$ & $\begin{array}{l}21.6(15,31) / \\
24.1(17,34)\end{array}$ & $\begin{array}{c}0.79 \\
(0.77-0.81)\end{array}$ \\
\hline High blood pressure & $\begin{array}{c}1619(1346,1928) / \\
1658(1364,1983)\end{array}$ & $\begin{array}{c}0.97 \\
(0.96-0.99)\end{array}$ & $\begin{array}{l}299(247,347) / \\
301(245,352)\end{array}$ & $\begin{array}{c}1.08 \\
(1.04-1.12)\end{array}$ & $\begin{array}{l}52.3(41,66) / \\
54.2(42,69)\end{array}$ & $\begin{array}{c}0.99 \\
(0.97-1.02)\end{array}$ & $\begin{array}{l}21.6(15,31) / \\
24.2(17,34)\end{array}$ & $\begin{array}{c}0.93 \\
(0.90-0.95)\end{array}$ \\
\hline Hyperglycemia & $\begin{array}{l}1616(1338,1927) / \\
1649(1362,1972)\end{array}$ & $\begin{array}{c}0.96 \\
(0.94-0.98) \\
\end{array}$ & $\begin{array}{l}297(245,345) / \\
301(246,352)\end{array}$ & $\begin{array}{c}0.93 \\
(0.90-0.97) \\
\end{array}$ & $\begin{array}{l}52.3(41,67) / \\
53.7(42,68)\end{array}$ & $\begin{array}{c}1.04 \\
(1.01-1.08)\end{array}$ & $\begin{array}{l}21.7(15,32) / \\
23.5(16,34)\end{array}$ & $\begin{array}{c}0.99 \\
(0.97-1.02)\end{array}$ \\
\hline
\end{tabular}




\section{nutrients}

Table 3. Odds ratio (OR) and 95\% confidence intervals (CI) of metabolic syndrome (MetS) according to macronutrient intake by age group, the HEXA-G study, 2004-2013

\begin{tabular}{|c|c|c|c|c|c|c|}
\hline & \multicolumn{3}{|c|}{ Men } & \multicolumn{3}{|c|}{ Women } \\
\hline & MetSa & Controla $^{a}$ & OR $(95 \% \mathrm{CI})^{\mathrm{b}}$ & MetSa $^{a}$ & Controla $^{\mathrm{a}}$ & OR $(95 \% \mathrm{CI})^{\mathrm{b}}$ \\
\hline \multicolumn{7}{|c|}{ Energy (kcal/day) } \\
\hline $40-49$ & $1875(1590,2241)$ & $1846(1568,2217)$ & $0.96(0.91-1.00)$ & $1699(1404,2044)$ & $1703(1393,2039)$ & $0.97(0.93-1.02)$ \\
\hline $50-59$ & $1778(1525,2111)$ & $1774(1511,2096)$ & $0.94(0.89-0.98)$ & $1632(1367,1937)$ & 1635 (1342,1947) & $0.97(0.94-1.00)$ \\
\hline $60-69$ & $1727(1473,2032)$ & $1711(1471,2013)$ & $0.97(0.92-1.02)$ & $1564(1310,1842)$ & $1571(1308,1865)$ & $0.97(0.92-1.01)$ \\
\hline \multicolumn{7}{|c|}{ Carbohydrate (g/day) } \\
\hline $40-49$ & $327(280,386)$ & $324(279,382)$ & $0.99(0.91-1.08)$ & $307(252,359)$ & $305(246,358)$ & $1.05(0.97-1.14)$ \\
\hline $50-59$ & $316(277,368)$ & $317(276,366)$ & $0.95(0.88-1.04)$ & $302(253,349)$ & $299(243,349)$ & $1.14(1.07-1.21)$ \\
\hline $60-69$ & $312(274,359)$ & $311(273,356)$ & $0.99(0.89-1.09)$ & $295(247,339)$ & $293(242,338)$ & $1.17(1.08-1.27)$ \\
\hline \multicolumn{7}{|c|}{ Protein (g/day) } \\
\hline 40-49 & $63.1(51,79)$ & $61.4(49,78)$ & $1.00(0.93-1.07)$ & $55.7(44,71)$ & $56.1(44,71)$ & $0.99(0.93-1.06)$ \\
\hline $50-59$ & $59.3(47,74)$ & $58.3(46,73)$ & $0.96(0.90-1.03)$ & $52.4(42,67)$ & $53.3(42,68)$ & $0.90(0.86-0.95)$ \\
\hline $60-69$ & $56.4(45,71)$ & $55.1(44,70)$ & $0.97(0.89-1.05)$ & $49.3(39,62)$ & $50.0(40,64)$ & $0.88(0.82-0.94)$ \\
\hline \multicolumn{7}{|c|}{ Fat (g/day) } \\
\hline 40-49 & $31.5(23,43)$ & $30.7(22,42)$ & $0.94(0.89-1.00)$ & $25.3(18,36)$ & $26.5(19,37)$ & $0.87(0.82-0.92)$ \\
\hline $50-59$ & $26.8(19,37)$ & $26.8(19,37)$ & $0.91(0.86-0.97)$ & $21.2(15,30)$ & $22.8(16,32)$ & $0.81(0.77-0.85)$ \\
\hline $60-69$ & $24.4(17,35)$ & $23.9(17,34)$ & $0.94(0.87-1.00)$ & $18.4(12,27)$ & $19.6(14,29)$ & $0.78(0.73-0.83)$ \\
\hline
\end{tabular}




\section{nutrients}

MDPI

A. Carbohydrate

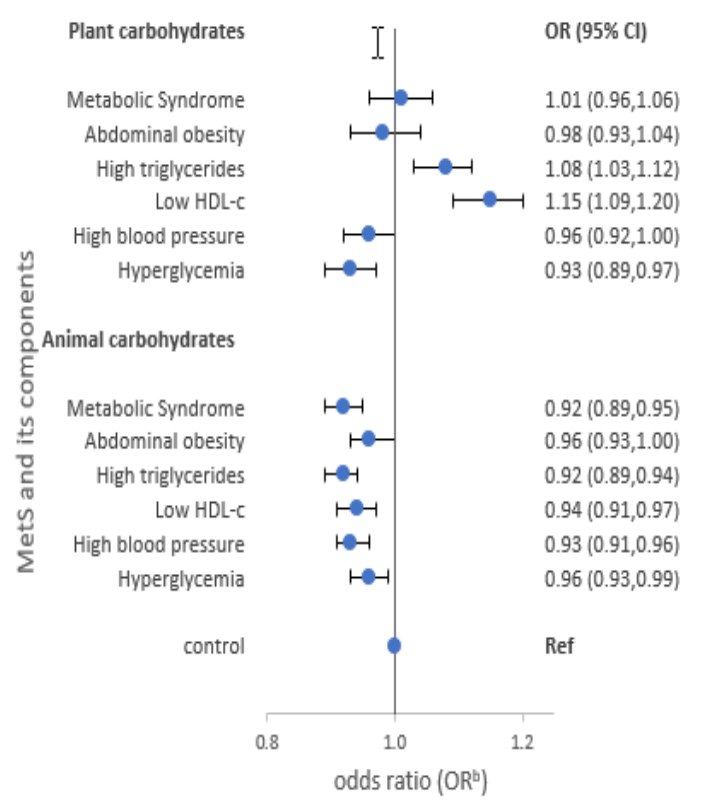

B.Protein

Plant protein

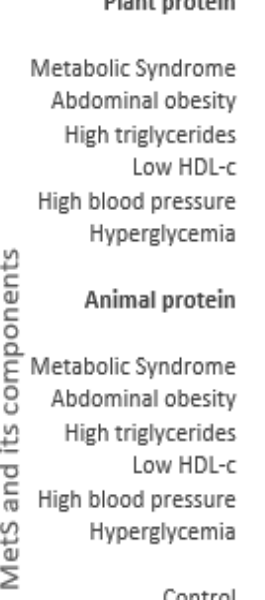

Control

0.8

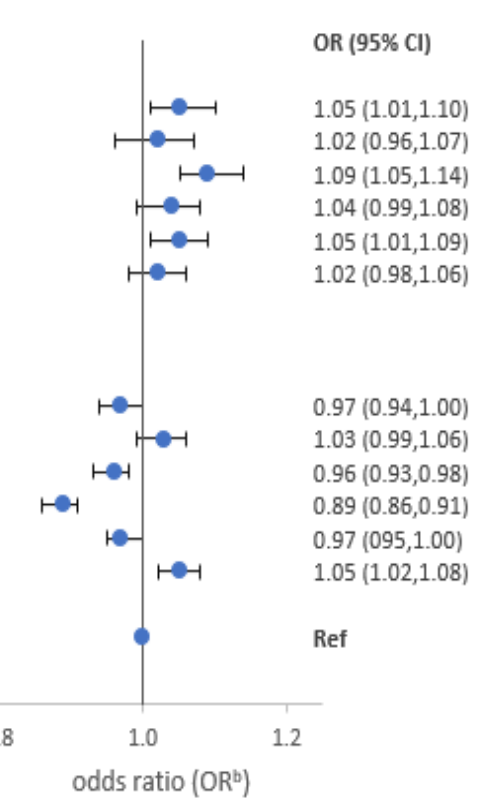

C.Fat

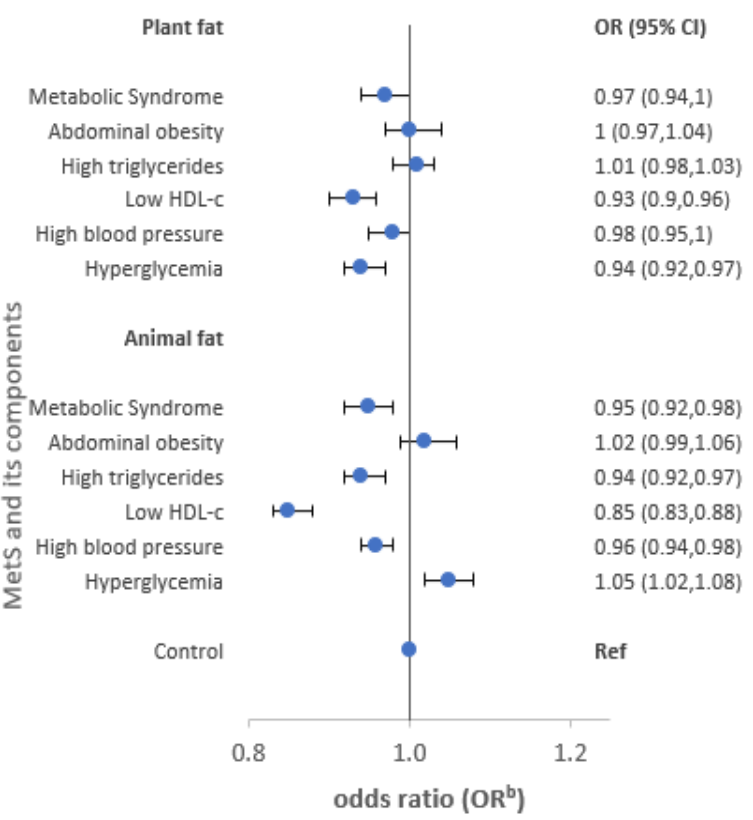

odds ratio $\left(O R^{\mathrm{b}}\right)$

Figure 2a. Odds ratio (OR) and 95\% confidence intervals (CI) of metabolic syndrome (MetS) and its components stratified by source of macronutrients in men, , 324 the HEXA-G study, 2004-2013 


\section{A. Carbohydrate}

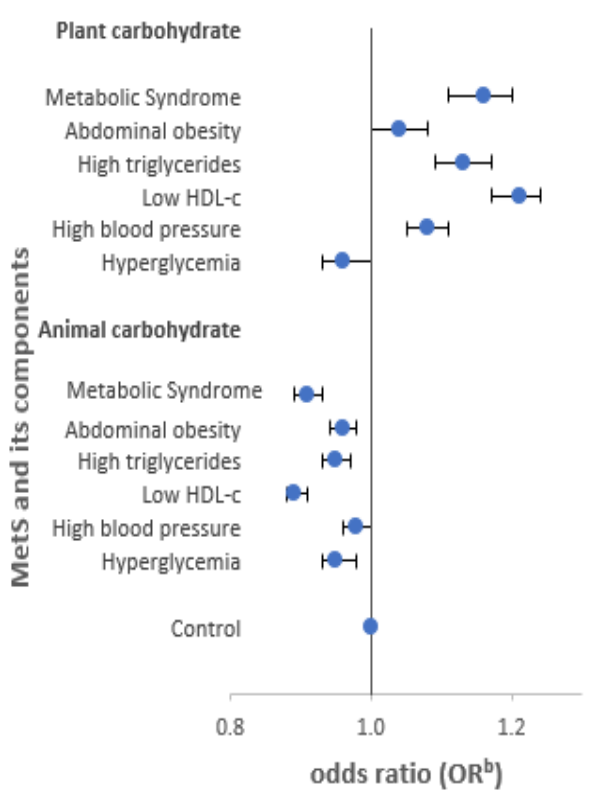

\section{B. Protein}

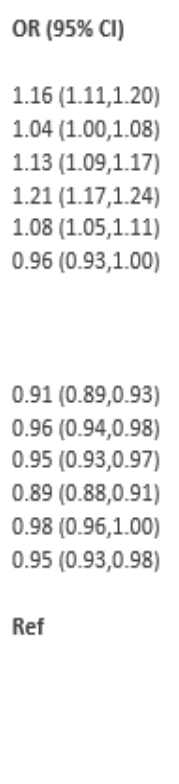

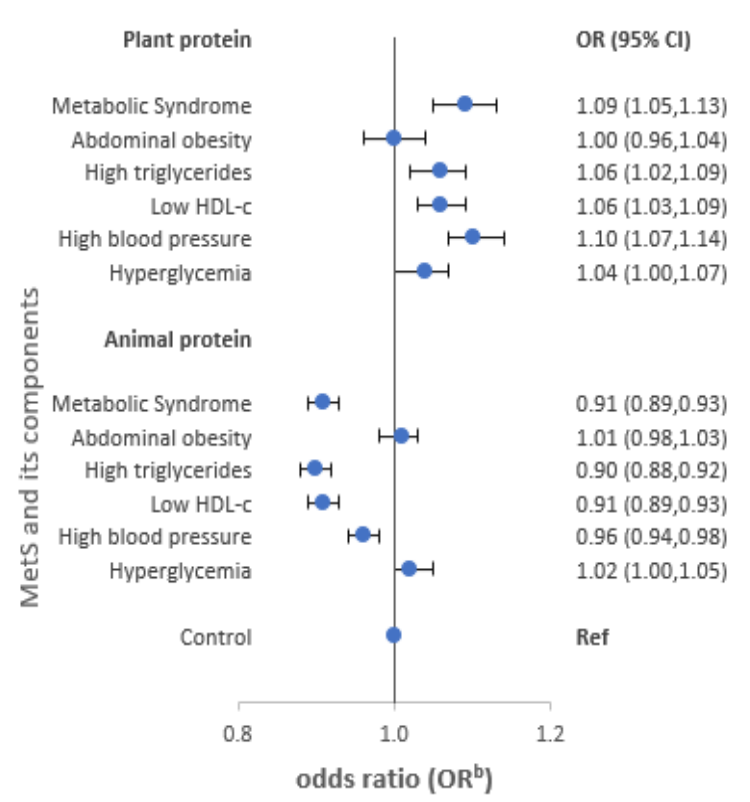

C. Fat

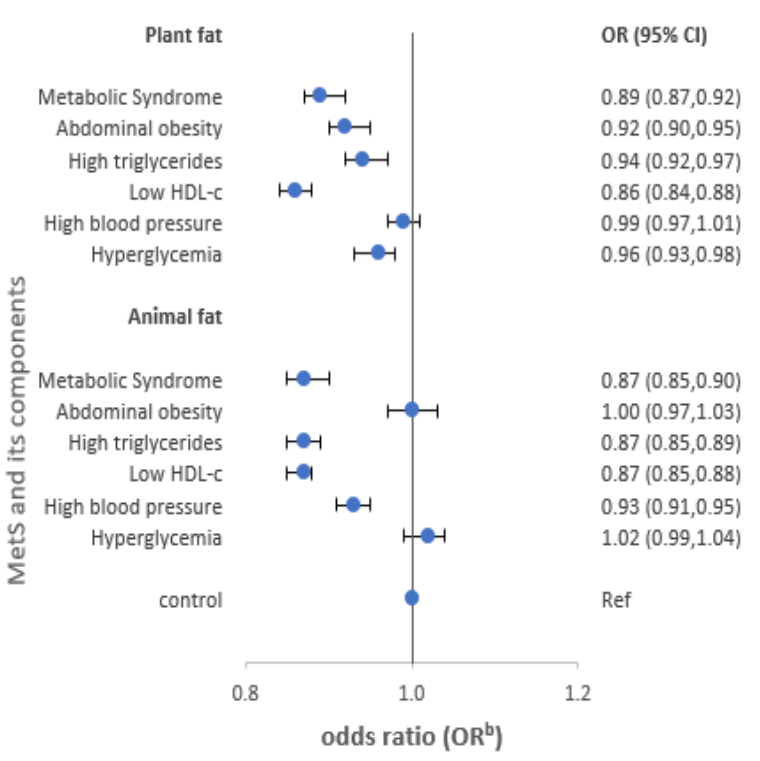

HDL-c: High density lipoprotein cholesterol.

b Adjusted for age, body mass index, marital status, education, family income, occupation, smoking, drinking, regular exercise, energy intake and menopausal status.

Figure $2 \mathrm{~b}$. Odds ratio (OR) and 95\% confidence intervals (CI) of metabolic syndrome (MetS) and its components stratified by source of macronutrients in women, , the HEXA-G study, 2004-2013 